\title{
Water Productivity of Cucumber and Tomato Crops as Affected by Different Cultural Substrates under Greenhouses Conditions at Bustan Area
}

\author{
Mahmoud, M. R.; Tarek, A. El-Ragal ${ }^{1}$ and M. A. Sayed ${ }^{2}$
}

\begin{abstract}
Greenhouses are considered as one of the feasible technologies for improving and propagating vegetables productivity per a unit of soil and water as well as for offseason productivity with higher net returns to the farmer. Two successive experiments were conducted at AbdelMonem Reyad Village at El-Bustan area in 2005 and 2006 seasons to study the effects of using different agricultural media on water productivity of cucumber and tomato and the economics of their production. The objective of these experiments was to study the effect of polyethylene ditches (30X0.3X0.2 $\mathrm{m}$ ditch dug in the soil, coated with polyethylene film and filled with fertile compost), the polyethylene beds (close polyethylene film and contain fertile compost with the dimensions of $3.0 \times 0.3 \times 0.2 \mathrm{~m}$. and punched for cucumber or tomato on $0.3 \mathrm{~m}$. and $0.5 \mathrm{~m}$.) and the polyethylene bags (bags from polyethylene each with the capacity of $4 \mathrm{~kg}$ of fertile compost on applied water, vegetative parameters and economical factors of cucumber and tomato under greenhouse conditions. Also, to find a solution to avoid using chemicals for sterilizing seedlings bed such as methyl bromide in sterilizing the soil, which is costly and a source of environmental pollution.
\end{abstract}

Results revealed that:

* There were some significant differences between the used treatments and the control on leaf area and dry matter parameters.

* Soil ditches Treatment had the highest significant yield for both cucumber and tomato crops.

* Applied water for both cucumber and tomato was measured and it increases with the vegetative growth increasing till the physiological maturity stage then decreased.

* Water productivity reached the highest value for polyethylene ditches treatment for cucumber and tomato greenhouse production.

* The net income for polyethylene ditches treatment reached $\mathbf{7 3 . 2}$ fold more than the traditional treatment for tomato, while, it reached $\mathbf{1 1 . 5}$ fold for cucumber.

\section{INTRODUCTION}

Cucumber (Cucumis sativus L.) is one of the favorite vegetable crops in Egypt, which is used as salad or pickle, and become the main produces crops in greenhouse crop in Egypt, because of its high return. Also, tomato is considered profitable in off season production inside greenhouses. However, there are some problems facing cucumber and tomato production in greenhouses, such as soil born diseases, soil salinity and excessive low temperature in winter even under plastic cover (Etman, et.al.; 2002).

Neveen, et.al (2008) reported that substrate cultures proved their abilities to be alternative method to produce high yield, and quality as well, of carnation flowers in the absence of methyl bromide fumigator. Using different substrate cultures would save the environment from pollutants by methyl bromide and also, it could worm the roots in excessive cold winter in case of using compost which would be reflects on the yield and yield quality. From the other hand they appeared economically visible relative to the traditional methods.

There are highly needs for more information about water requirements for tomato and cucumber, and water productivity under the tested variables.

Irrigation scheduling using the climatic data is still generally used (Abu-Khalid, et.al.1988). In greenhouses, under Mediterranean climate the class A pans evaporation method as well as the radiation (FAO) and Priestly-Taylor methods are presumed to give reliable results of water requirements of protected crops (Graaf, et.al.,(1981), Doorebos and Pruntt,1984. and Abou Hadid,1993).

\section{MATERIALS AND METHODS}

Two experiments were carried out in 2005 and 2006 seasons at Abdel-Monem Ryad Village, El-Bustan area to study the effects of different cultural substrates on water productivity and economics of producing cucumber and tomato in greenhouses. The tested cultural substrates were polyethylene ditches, polyethylene beds, polyethylene bags and the farmer traditional method (soil fumigated with methyl bromide).

The polyethylene ditches were (spaces $30 \mathrm{X} 0.3 \mathrm{X}$ $0.2 \mathrm{~m}$ ) ditch dug in the soil, coated with polyethylene film and filled with fertile compost. The polyethylene beds were close polyethylene film containing fertile compost with the dimensions of $3.0 \times 0.3 \times 0.2 \mathrm{~m}$ and punched for cucumber or tomato on $0.3 \mathrm{~m}$ and $0.5 \mathrm{~m}$, respectively. The polyethylene bags were bags from

\footnotetext{
${ }^{1}$ Horticulture Research Institute, Agricultural Research Center.

${ }^{2}$ Soil, Water and Environment Research Institute,

Agricultural Research center.

Received December3, 2008, Accepted December 29, 2008
} 
polyethylene ach with the capacity of $4 \mathrm{~kg}$ of fertile compost. The bags were arranged according to the spacing of $0.3 \mathrm{~m}$. for cucumber and $0.5 \mathrm{~m}$. for tomato. The traditional (farmer practice or control) was the natural soil fumigated with methyl bromide.

Trickle irrigation system was used for irrigation. The system consists of sub main PVC pipe $63 \mathrm{~mm}$ outdiameter and a sub-sub main for each greenhouse 40 $\mathrm{mm}$ out-diameter P.E. pipe. The drip lines had GR 2 1/h emitter spaced $0.5 \mathrm{~m}$. A fertilizer injector was connected to the system for fertigation and a flow meter to measure the applied water.

Cucumber (Cucumis sativus L.) hybrid seedlings Pasandra Varity were planted on 4/11/2005 and $5 / 11 / 2006$ for the first and second seasons, respectively. Tomato (Lycopersicon esculentum L.) hybrid seedlings Thomspn variety, were transplanted on 10/11 and 20/11 for the first and second seasons, respectively.

The leaf area vegetative parameter was measured randomly in five plants from cucumber and tomato from each treatment, 75 days after transplanting and leaf thinning in tomato in the greenhouse (DAT). For dry matter content, of random fruits, samples from each fresh fruits were dried to determine the dry matter $\mathrm{g} / \mathrm{kg}$ fresh fruits. The leaf area per plant was measured by taken five plants randomly from each treatment and the leaf area was determined as follows:

The leaves weighed freshly without petioles. Twenty random discs were taken from different detached leaf parts using a cork puncher and weighed. The leaf area per plant was calculated according to the following formula:

fresh Weight of leaves $X$ area of 20 discs Leaf area per plant $=$

Fresh Weight of 20 discs

Table 1. Soil Physical and chemical analysis
Dry matter content of fresh fruits (Cucumber and Tomato) were determined by weighing the fresh fruit and drying it in an oven at $70{ }^{\circ} \mathrm{C}$ till a constant weight was attained, and then, the percentage of dry matter content was calculated after 75 DAT from the following formula:

$\%$ Dry matter $=\frac{\text { Dry weight }}{\text { Freshweight }} X 100$

Applied water was measured by flow meter, and water productivity in terms of $\mathrm{kg}$ fresh fruit weigt $/ \mathrm{m}^{3}$ applied water, was calculated according to the formula described by Jensen. (1983)., as follows:

Cucumber or tomato fresh fruit weight $(\mathrm{kg})$

Water productivity $=$

$$
\text { Applied Water in (cubic meters) }
$$

The potential evapotranspiration was obtained from class A pan measurements as by the formula:

$\mathrm{ETo}=\mathrm{E}$ pan X K pan

Where;

$\mathrm{E}$ pan $=$ measured pan evaporation daily values in $\mathrm{mm} / \mathrm{day}$,

$\mathrm{K}$ pan = pan coefficient, values depend on relative humidity, wind speed and site conditions (bare or cultivated). A value of 0.75 was used.

ETc = actual crop evapotranspiration and calculated by soil sampling before and after irrigation.

$\mathrm{Kc}=$ crop coefficient, it was calculated from the formula:

$$
\mathrm{Kc}=\frac{\text { ETO }}{\text { ETC }}
$$

Soil and fertile compost samples were collected from the experimental site for physical and chemical analysis according to Page, (1984) and results are shown in Tables 1 and 2.

\begin{tabular}{|c|c|c|c|c|c|c|c|c|c|c|}
\hline \multirow{2}{*}{$\begin{array}{l}\text { Depth } \\
\text { Cm. }\end{array}$} & \multirow{2}{*}{$\begin{array}{l}\text { E.C } \\
\text { Ds/m } \\
\end{array}$} & \multirow[t]{2}{*}{ pH } & \multicolumn{8}{|c|}{ Soluble cations and anions ( $\mathrm{mequ} / / \mathrm{I})$} \\
\hline & & & $\mathbf{C a}^{++}$ & Mg++ & $\mathrm{Na}^{+}$ & $\mathbf{K}^{+}$ & $\mathrm{CO}_{3}^{--}$ & $\mathrm{HCO}_{3}^{-}$ & $\mathrm{Cl}^{-}$ & SO4-- $^{-1}$ \\
\hline $0-30$ & 0.35 & 9.13 & 1.23 & 0.54 & 1.56 & 0.17 & ---- & 1.10 & 1.73 & 0.67 \\
\hline $30-60$ & $0 . .30$ & 9.38 & 1.25 & 0.49 & 1.61 & 0.15 & ---- & 1.07 & 1.74 & 0.69 \\
\hline \multicolumn{11}{|c|}{ B) The physical soil properties for El-Bustan location. } \\
\hline \multicolumn{3}{|c|}{ Depth (cm.) } & \multicolumn{3}{|c|}{ (Bulk density) g./cm ${ }^{3}$} & \multicolumn{3}{|c|}{ (PWP) \% } & \multicolumn{2}{|c|}{$(\mathrm{FC}) \%$} \\
\hline \multicolumn{3}{|c|}{$0-15$} & \multirow{2}{*}{\multicolumn{3}{|c|}{$\begin{array}{l}1.65 \\
1.67\end{array}$}} & \multicolumn{3}{|c|}{6.80} & \multicolumn{2}{|c|}{15.61} \\
\hline \multicolumn{3}{|c|}{$15-30$} & \multirow{2}{*}{\multicolumn{3}{|c|}{$\begin{array}{l}1.67 \\
170\end{array}$}} & \multicolumn{3}{|c|}{6.78} & \multicolumn{2}{|c|}{15.39} \\
\hline \multirow{2}{*}{\multicolumn{3}{|c|}{$30-45$}} & & & & \multicolumn{3}{|c|}{5.99} & \multicolumn{2}{|c|}{11.01} \\
\hline & & $45-60$ & \multicolumn{3}{|c|}{1.74} & \multicolumn{3}{|c|}{5.97} & \multicolumn{2}{|c|}{10.99} \\
\hline
\end{tabular}

A) The chemical analysis of soil samples for El-Bustan location.

C) Siol Texture and its fractions for El-Bustan location.

$\begin{array}{lllll}\text { Depth cm. } & \text { Sand \% } & \text { Silt \% } & \text { Clay \% } & \text { Texture Class }\end{array}$




\begin{tabular}{ccccc}
\hline $0: 30$ & 90.9 & 2.6 & 6.5 & Sandy \\
$30: 60$ & 91.0 & 1.8 & 7.2 & Sandy \\
\hline
\end{tabular}

Table 2. Compost analysis

\begin{tabular}{cccc}
\hline Element & Content of fertile compost & Element & Content of fertile compost \\
\hline Total Phosphorous & $0.68 \%$ & $\mathrm{pH}(1: 10)$ & 8.5 \\
Total Potassium & $0.65 \%$ & $\mathrm{EC}(1: 10)$ & $7.5 \mathrm{dSm}^{-1}$ \\
Total N & $1.5 \%$ & $\mathrm{Fe}$ & $1700 \mathrm{ppm}$ \\
Organic carbon & $25.2 \%$ & $\mathrm{Mn}$ & $220 \mathrm{ppm}$ \\
Organic Matter & $45 \%$ & $\mathrm{Cu}$ & $1 \mathrm{ppm}$ \\
& & $\mathrm{Zn}$ & $150 \mathrm{ppm}$ \\
& & $\mathrm{Mg}$ & $700 \mathrm{ppm}$ \\
\hline
\end{tabular}

The experimental design was randomized complete blokes design (RCBD) with three replicates.

\section{Economic analysis}

Economic analysis was based on the total income, variable costs and net revenue.

Total income $=$ Total yield $\mathrm{X}$ unit price .

Variable coasts $=$ sum (all production coasts)

Net revenue $=$ Total income - Variable coasts.

\section{Statistical analysis:}

Obtained data were analyzed using the software CoHort (1986) statistical package. The average values of the replicates of each treatment were interpreted using the analysis of variance (ANOVA). The Duncan's multiple range tests for comparisons between means according to Steel and Torrie (1980).

\section{RESULTS AND DISCUSSION}

\section{Vegetative growth:}

Leaf area and fruit dry matter content are two important parameters reflect the response of crop vegetative growth and obtained yield of both cucumber and tomato. Figures 1and 2 illustrate the leaf area $\left(\mathrm{cm}^{2}\right)$ for cucumber and tomato as affected by the four treatments, respectively. The figures show that there are significant increases in the leaf area at the tested variables in the two growing seasons (2005 and 2006) as compared to the farmer traditional treatment (control). The treatment (soil ditches) had the highest values of leaf area for both cucumber and tomato in the two growing seasons. These values were 3000, 3200, 180 and 200 $\left(\mathrm{cm}^{2}\right)$ for cucumber 2005, cucumber 2006, tomato 2005 and tomato 2006, respectively. Figures 3 and 4 presented the obtained results for fruits dry matter $(\mathrm{g} / \mathrm{kg})$ for cucumber and tomato in the two growing seasons 2005 and 2006, respectively. For cucumber (Table 3) there was no significant increase in dry matter for fruits at the two growing seasons 2005 and 2006. But, for tomato (Table 4) there was significant increase between soil ditches \& soil beds and traditional treatment, a significant increase between soil bags and the control treatment in the two growing seasons. The obtained data were in agreement with Etman, et.al.2001, Tawfik, et.al.2004 and Neveen,et al., (2008).

\section{$\square 2005 \square 2006$}

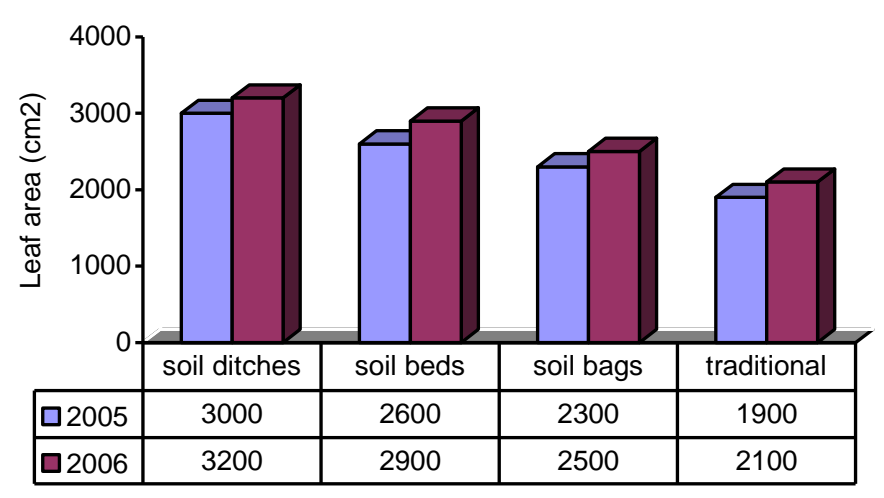

Tested variables

LSD $0.05(2005)=339.435$

LSD $0.05(2006)=339.435$ 
Figure 1. The effect of tested variables on cucumber leaf area $\left(\mathrm{cm}^{2}\right)$ DAT

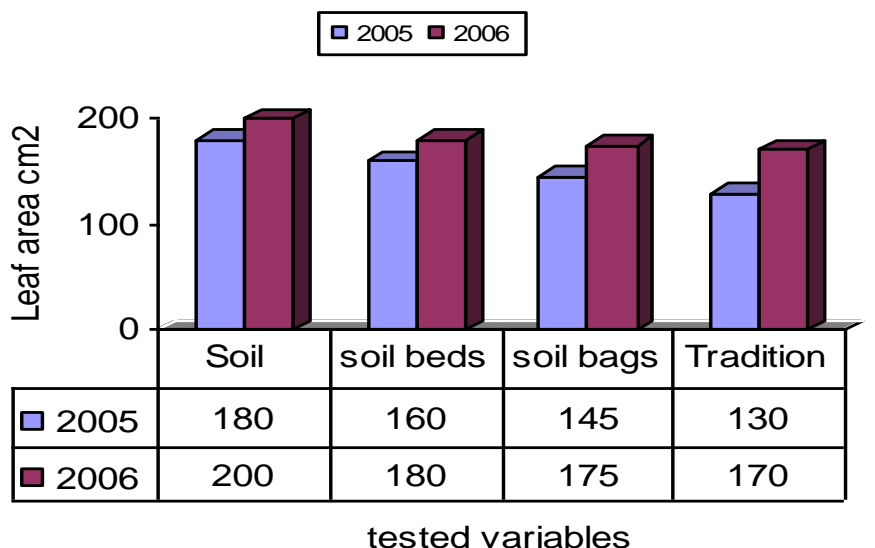

LSD $0.05(2005)=18.824$

LSD $0.05(2006)=26.627$

Figure 2. The effect of tested variables on leaf area $\left(\mathrm{cm}^{2}\right)$ for tomato 75 DAT and after leaf thinning $\square 2005 \square 2006$

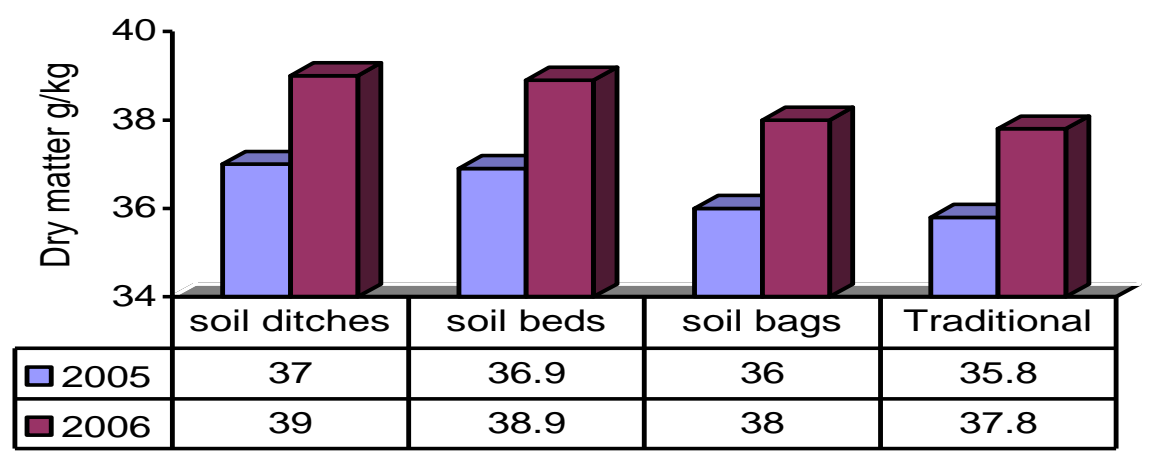

Tested variables

LSD $0.05(2005)=1.331$

LSD $0.05(2006)=1.310$

Figure 3. The effect of tested variables on dry matter in cucumber fruit $(\mathrm{g} / \mathrm{kg})$

$\square 2005 \square 2006$

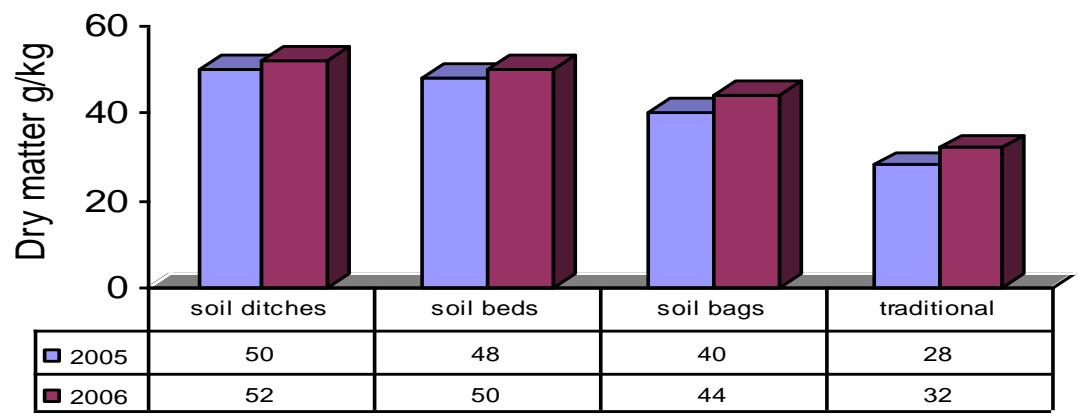

Tested variables

LSD $0.05(2005)=5.879$

$\operatorname{LSD} 0.05(2006)=5.242$ 


\section{Figure 4. The effect of tested variables on fruit dry matter in tomato $\mathrm{g} / \mathrm{kg}$}

\section{Fresh fruit yield}

\section{a) Cucumber yield}

Results in Table 3 shows the yield of cucumber, applied water and water productivity in the two growing seasons (2005 and 2006) as affected by the tested variables. Results indicated that there are highly significant increases on the yield of cucumber among the polyethylene ditches, polyethylene beds, polyethylene bags and the farmer traditional method (soil fumigated with methyl bromide).

The measured applied water varies among the treatments because the wetted areas varied in polyethylene ditches, polyethylene beds, polyethylene bags and the farmer traditional method and their values were 194.4, 216, 156.9 and $297 \mathrm{~m}^{3} /$ season, respectively for 2005 season. The same trend was observed for 2006 season.

\section{Table 3. Fresh fruit of cucumber, applied water and} 2006 growing seasons

\begin{tabular}{|c|c|c|c|}
\hline \multirow[b]{2}{*}{ Treatment } & \multicolumn{3}{|c|}{2005 season } \\
\hline & Ton/greenhouse & $\begin{array}{c}\text { Applied water } \\
\text { (mseason) }\end{array}$ & $\begin{array}{l}\text { Water productivity } \\
\left(\mathrm{Kg} \text { fresh fruit/m } \mathbf{m}^{3}\right)\end{array}$ \\
\hline Polyethylene ditches, & $4.6 \mathrm{a}$ & 194.4 & 23.66 \\
\hline polyethylene beds, & $3.2 \mathrm{~b}$ & 216 & 14.81 \\
\hline polyethylene bags & $3.1 \mathrm{~b}$ & 156.6 & 19.79 \\
\hline farmer traditional & $3.0 \mathrm{c}$ & 297 & 10.10 \\
\hline \multirow[b]{2}{*}{ Treatment } & \multicolumn{3}{|c|}{2006 season } \\
\hline & Ton/greenhouse & $\begin{array}{c}\text { Applied water } \\
\left(\mathrm{m}^{3} / \text { season) }\right.\end{array}$ & $\begin{array}{l}\text { Water productivity } \\
\left(\mathrm{Kg} \text { fresh fruit/m } \mathbf{m}^{3}\right)\end{array}$ \\
\hline polyethylene ditches, & $4.2 \mathrm{a}$ & 188.6 & 22.27 \\
\hline polyethylene beds, & $3.5 \mathrm{~b}$ & 207.5 & 16.87 \\
\hline polyethylene bags & $3.3 \mathrm{~b}$ & 150.9 & 21.37 \\
\hline farmer traditional & $3.0 \mathrm{c}$ & 270 & 11.11 \\
\hline
\end{tabular}

Table 4. Fresh fruit yield of tomato, applied water and water productivity for the 2005 and 2006 growing seasons

\begin{tabular}{|c|c|c|c|}
\hline \multirow[t]{2}{*}{ Treatment } & \multicolumn{3}{|c|}{2005 season } \\
\hline & Ton/greenhouse & $\begin{array}{c}\text { Applied water } \\
\left(\mathrm{m}^{3} / \text { season }\right)\end{array}$ & $\begin{array}{l}\text { Water productivity } \\
\left.\text { (Kg fresh fruit/m }{ }^{3}\right)\end{array}$ \\
\hline polyethylene ditches, & $3.49 \quad \mathrm{a}$ & 291.6 & 11.96 \\
\hline polyethylene beds, & $2.9 \mathrm{a}$ & 324 & 8.95 \\
\hline polyethylene bags & $2.64 \mathrm{~b}$ & 236 & 11.2 \\
\hline farmer traditional & $2.3 \mathrm{~b}$ & 447 & 5.15 \\
\hline \multirow[t]{2}{*}{ Treatment } & \multicolumn{3}{|c|}{2006 season } \\
\hline & Ton/greenhouse & $\begin{array}{c}\text { Applied water } \\
\left(\mathbf{m}^{3} / \text { season }\right)\end{array}$ & $\begin{array}{l}\text { Water productivity } \\
\text { (Kg fresh fruit/m }\end{array}$ \\
\hline polyethylene ditches, & $3.62 \mathrm{a}$ & 283.5 & 12.77 \\
\hline polyethylene beds, & $3.1 \mathrm{a}$ & 310.5 & 9.98 \\
\hline polyethylene bags & $2.62 \mathrm{~b}$ & 225 & 11.64 \\
\hline farmer traditional & $2.72 \mathrm{~b}$ & 405 & 6.72 \\
\hline
\end{tabular}


The measured applied water varies among the treatments because of the wetted areas varied in polyethylene ditches, polyethylene beds, polyethylene bags and the farmer traditional method and its values were 291.6, 324, 236 and 447, respectively in 2005 season and the same trend was observed in 2006 season.

Water productivity in $\mathrm{kg}$ fresh cucumber fruits per applied water in cubic meters was higher in the treatments polyethylene ditches, polyethylene beds, polyethylene bags than the value of control treatment. These values reached 11.96, 8.95, 11.2 and 5.15 for polyethylene ditches, polyethylene beds, polyethylene bags and the control, respectively in 2005 season. The same trend was observed in 2006 season.

3 Water consumptive use, reference evapotranspiration and crop coefficient:

Monthly water consumptive use (ETc), reference evapotranspiration (ETo) and crop coefficient $(\mathrm{Kc})$ for cucumber are presented in Table 5, where the same data are presented for tomato in Table 6. Results showed that values of water consumption by both cucumber and tomato increased from the vegetation stage to flowering and to yield formation stage, they decreased at ripening stage. The total water consumptive use for cucumber was 84.4 and $81.8 \mathrm{~m}^{3} /$ greenhouse for 2005 and 2006 growing seasons, respectively. For tomato, the total water consumptive use was 135.2 and 131.4 $\mathrm{m}^{3} /$ greenhouse for 2005 and 2006 seasons, respectively. ETo values represents the evaporation through the growing seasons. The average crop coefficient of cucumber under greenhouse conditions was 0.343 and for tomato it was 0.462 . The $\mathrm{Kc}$ values increased from the initial state to the vegetative, flowering and then decreased with ripening stage for the two growing crops.

\section{Economic analysis:}

Tables 7 and 8 present average variable coasts, total income and net revenue for cucumber and tomato under greenhouse conditions and different cultural substrate. From Tables 7 and 8 data showed that:

- The highest average net income was achieved from polyethylene ditches treatment for both cucumber and tomato.

- The lowest average net revenue was for the traditional method (farmer practice).

- The net revenue for polyethylene ditches treatment has increase with $73 \%$ than the traditional one.

\section{Table 5. Water consumptive use for cucumber under greenhouse condition, ETo and Ke}

\begin{tabular}{|c|c|c|c|}
\hline \multirow[t]{2}{*}{ Months } & \multicolumn{3}{|c|}{2005} \\
\hline & ETo $\mathrm{m}^{3} /$ greenhouse & ETc $\mathrm{m}^{3} /$ greenhouse & Kc \\
\hline Nov. & 18.58 & 4.645 & 0.25 \\
\hline Dec. & 62.59 & 30.889 & 0.49 \\
\hline Jan. & 68.90 & 37.566 & 0.54 \\
\hline Feb. & 25.16 & 11.322 & 0.45 \\
\hline \multirow[t]{2}{*}{ Months } & \multicolumn{3}{|c|}{2006} \\
\hline & ETo $\mathrm{m}^{3} /$ greenhouse & ETc m3/greenhouse & Kc \\
\hline Nov. & 18.66 & 4.536 & 0.24 \\
\hline Dec. & 60.58 & 29.995 & 0.50 \\
\hline Jan. & 66.726 & 36.39 & 0.55 \\
\hline Feb. & 24.435 & 10.93 & 0.45 \\
\hline
\end{tabular}

Greenhouse area is $270 \mathrm{~m}^{2}$.

Table 6. water consumption use for tomato under greenhouse conditions (ETc), ETo and Kc

\begin{tabular}{|c|c|c|c|}
\hline \multirow[t]{2}{*}{ Months } & \multicolumn{3}{|c|}{2005} \\
\hline & ETo $\mathrm{m}^{3} /$ greenhouse & ETc m³/greenhouse & Kc \\
\hline Nov. & 17.5 & 7.00 & 0.4 \\
\hline Dec. & 70.1 & 35.05 & 0.5 \\
\hline Jan. & 87.5 & 56.88 & 0.65 \\
\hline Feb. & 68.5 & 30.83 & 0.45 \\
\hline March & 16.7 & 5.46 & 0.31 \\
\hline \multirow{2}{*}{ Months } & \multicolumn{3}{|c|}{2006} \\
\hline & ETo $\mathrm{m}^{3} /$ greenhouse & ETc m³/greenhouse & Kc \\
\hline Nov. & 17.0 & 6.8 & 0.4 \\
\hline Dec. & 68.0 & 34.0 & 0.5 \\
\hline Jan. & 85.0 & 55.3 & 0.65 \\
\hline Feb. & 67.0 & 30.2 & 0.45 \\
\hline March & 16.5 & 5.1 & 0.31 \\
\hline
\end{tabular}


Greenhouse area is $270 \mathrm{~m}^{2}$.

Table7. The total income, variable coasts and net income for cucumber 9average of the two seasons in L.E

\begin{tabular}{lccc}
\hline Treatment & $\begin{array}{c}\text { (Total income) } \\
\text { (L.E.) }\end{array}$ & $\begin{array}{c}\text { (Variable coasts). } \\
\text { (L.E.) }\end{array}$ & $\begin{array}{c}\text { Average net revenue } \\
\text { (L.E) }\end{array}$ \\
\hline polyethylene ditches, & 2482.5 & 1276.2 & 1206.3 \\
polyethylene beds, & 1660 & 1480.2 & 179.8 \\
polyethylene bags farmer & 1734.75 & 1258.2 & 476.55 \\
traditional & 1613.25 & 1505.7 & 107.55 \\
\hline
\end{tabular}

Table 8. The total income, variable coasts and net income for tomato average of the two seasons in L.E

\begin{tabular}{lccc}
\hline Treatment & $\begin{array}{c}\text { (Total income) } \\
\text { (L.E.) }\end{array}$ & $\begin{array}{c}\text { (Variable coasts). } \\
\text { (L.E.) }\end{array}$ & $\begin{array}{c}\text { Average net revenue } \\
\text { (L.E) }\end{array}$ \\
\hline polyethylene ditches, & 2593.1 & 813.2 & 1779.9 \\
polyethylene beds, & 1652.2 & 1001.5 & 650.7 \\
polyethylene bags farmer & 1817.89 & 800.2 & 1017.8 \\
traditional & 1446.3 & 1200 & 246.3 \\
\hline
\end{tabular}

Greenhouse area is $270 \mathrm{~m}^{2}$.

\section{REFERENCES}

Abou-Hadid,A.F.1993. Climate factors in plastic houses and their possible effect on plant water requirements. In workshop on Environmentally sound use of waterof agriculture under Mediterranean areas and arid climatic areas. Bari, Italy.

Abou-Khalid,A.;J.Van hve and A.R.Al Youssk.1988.Evapotranspiration formula adjusted to plastic tunnels in Egypt. Preliminary results. FAO Technical Report No. 6653 Cairo, Egypt.

Castilla, N. 1993. Greenhouse drip irrigation management for Mediterranean areas. In workshop on Environmentally sound use of water of agriculture under Mediterranean areas and arid climatic areas. Bari, Italy.

CoHort Software. 1986. Costat statistical package (version 3.03) P.OBox 1149, Berkeley, CA 94701, USA.

Doorenbose, J. and W.O. Pruitt. 1984. Guidelines for predicting crop water requirements. FAO Irrigation and Drainage paper No. 24 Rome, Italy.
Etman, A.; F. El-Aidy; N. Hassan; H. El-Dwany and Manal, a. abd-Alla. 2002. Effect of grafting cucumber onto different rootstocks on vegetative growth and yield under plastic tunnels $2^{\text {nd }}$ international Cno. Hort. Sci., 10-12 Sep. 2002, Kafr El-Sheikh, Tanta University, Egypt, pp.54-64.

Greaf, R.de. And J. V. D. Ende. 1981. Transpiration and evapo-transpiration of glass house crops. ACTA Hort. 119:147-158.

Israelson, O. W. and V. E. Hansen. 1962. Irrigation principles and practices. John Willy and Sons, Inc. New York.

Jensen, M.E.1983. Design and operation of farm irrigation systems. ASAE, Michigan, USA. P827.

Page, A.L.; R. H. Miller and D. R. Keeny. 1982. Methods of soil analysis. Amer. Soc. Agr. Inc. Madison, USA.

Tawfik, H. hamdy, Y. A. and Mohamed, A. Saied. 2004. Organic farming between theory and application. ISBN. :977-302-109-2 ( $1^{\text {st }}$ edition $)$.

Nveen, E. Metwally; S. A. El-Gindy; A. F. Abou-Hadid and U. A. El-Behairy. 2008. Effect of different substrates on production and quality of carnation. IDDC, $9^{\text {th }}$ Conference on dry development 


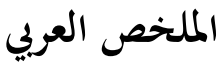

\section{الإنتاجية المائية لححصولى الحيار والطماطم المنزرعة تحت ظرف البيوت البلاستيكية وتحت بيئات زراعية مختلفة بمنطقة البستان}

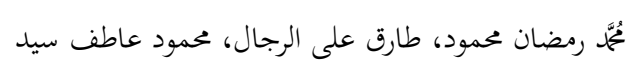

للخيار ليس لها فروقاً معنوية في موسمى النمو 2005 و 2006 بينما مع مصول الطماطم كانت هناك فروق معنويه بين المادة الجافة بالثمار الطازجة وعاملات التجربة.

3. بالنسبة للمحصول الطازج من كل من الخيار والطماطم أوضحت

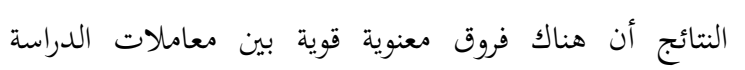
ومعاملة المزارع ·

4. وجد أن الإستهلاك المائى لمحصولى الخيار والطماطم يزداد من أطوار النمو الخضرى المى الإزهاروالإثمار تم يقل في مرحلة النضج.

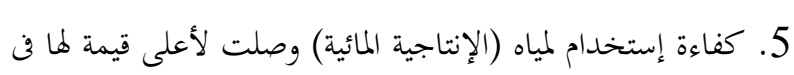
معاملة الخنادق البلاستيكية.

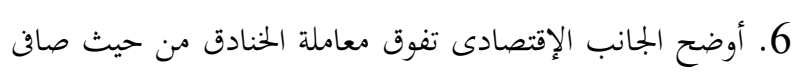

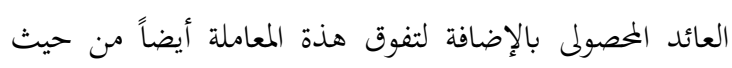

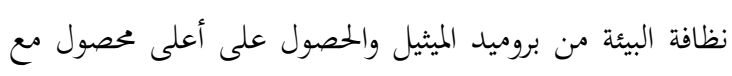
تقليل التكاليف المتغيرة.
أجريت تجربتان حقليتان بالبيوت البلاستيكية بمنطقة البستان قرية عبد المنعم رياض عامى 2005 و2006 لدراسة تأثير استخدام

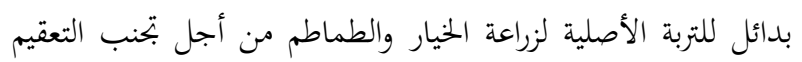

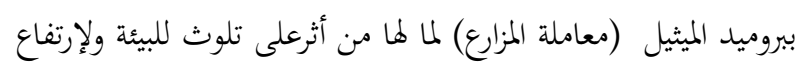

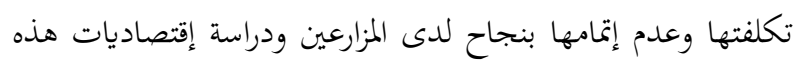

$$
\text { البدائل. }
$$

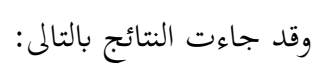

1. أوضحت القياسات الخضريه (المساحة الورقية) على مدى عامى

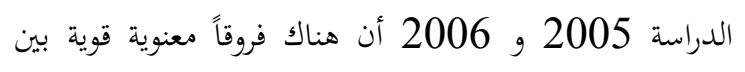
المعاملات تحت الدراسة وطريقة المزارع التقليدية وكانت أحسنهم على التوالى معاملة الخنادق بالبلاستك تم الوسائد البلاستيكية

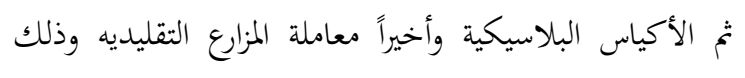
لمعصولى الخيار والطماطم المنزرعة داخل البيوت البلاستيكية.

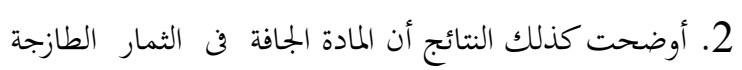

